\title{
INTRODUCTION
}

\section{Prophecy and Diplomacy: The Moral Teaching of John Paul II}

FOR A DECADE, the John Paul II Symposium has gathered Jesuit scholars for a biennial conference to explore the teaching of John Paul II. Interdisciplinary, the symposium features specialists from the fields of theology, philosophy, history, sociology, economics, and political science. Pluralist, the symposium fosters debate among Jesuits representing different positions on the theological and political spectrum. Jesuit, the symposium places scholarly research at the service of sentire cum ecclesia, the reverential "thinking with the Church" that has characterized the Society of Jesus since its origin.

The symposium has sponsored five conferences on major issues in the pontificate of John Paul II. The 1990 Loyola-Chicago conference focused on the global thought of John Paul II. The 1992 Fordham-New York conference studied his ecclesiology. The 1994 Canisius-Buffalo conference examined the pope's fundamental moral theology. The 1996 Georgetown-Washington conference analyzed his applied ethical theory. The 1998 Georgetown-Washington conference discussed millennial themes in the documents of the pope.

An earlier volume edited by John M. McDermott, S.J., The Thought of John Paul II (Rome: Gregorian University Press, 1993), drew primarily upon papers from the 1990 Loyola and the 1992 Fordham conferences to provide a synthetic portrait of the pope's distinctive philosophy and theology.

The current volume focuses upon the moral teaching of John Paul II. It incorporates papers, responses, and colloquia summaries 
from the 1994 Canisius and 1996 Georgetown conferences. Following the conference topics, the first part explores the general moral teaching of the pope, while the second part examines his ethical positions in specific areas of human action.

The decision of the symposium to concentrate upon the moral theory of John Paul II was an obvious one. The arguments of the Catholic Church on ethical issues have constituted a perennial object of scholarly debate. Several factors have created a special prominence for the moral pronouncements of this pontificate.

First, it is moral questions that most palpably divide the Catholic community, especially in the West. The polemic over contraception in the 1960s has broadened into a systematic opposition to Church doctrine on sexual conduct, family life, and human life issues. More conservative critics challenge Church positions on property rights, internationalism, and just war. Never has the Church issued so many statements on moral conduct. But the directives increasingly fall on a Catholic population more attentive to the magisterium of Oprah than to the narrow road of the gospel.

Astute observers, including many contributors to this volume, interpret the moral confusion of the Catholic community as a symptom of a deeper crisis of faith. Pastoral practice and sociological polls attest a patent erosion of belief in such basic beliefs as the divinity of Christ. Increasingly, North American Catholicism has the air of a flat deism wrapped in Christmas twinkle lights. Nevertheless, it is in the moral sphere that the anguish of the contemporary Church most powerfully manifests itself. John Paul II has constructed a veritable library of documents dealing with the most neuralgic moral controversies: sexuality (Familiaris Consortio, 1981); the role of women (Mulieris Dignitatem, 1988); economic relations (Sollicitudo Rei Socialis, 1987); the right to life (Evangelium Vitae, 1995). As his reign matures, the pope has developed a more detailed theory of the broader moral issues, such as conscience and law, shaping the surface controversies over sexuality and social justice.

Second, the moral teaching of John Paul II regularly incites political controversy. In the earlier part of his pontificate, the pope elaborated a vigorous "gospel of human rights." His writ- 
ings both reflected and stimulated the Church's resistance to totalitarian and authoritarian regimes. The collapse of Communism in Eastern Europe and of militarist regimes in Latin America derived in no small part from the rights crusade engineered by the pope and his allies. In the latter part of his pontificate, with the resurgence of parliamentary democracies, the terms of the Church's ethical critique of the political order have shifted. John Paul II has increasingly criticized the tendency of contemporary democracy to deteriorate into an arbitrary rule of the majority rather than to be faithful to its rightful vocation as the defender of the rights of vulnerable minorities. Recent United Nations conferences at Cairo (1994) and Beijing (1995) provided a diplomatic background for the growing dispute between the pope and the secular West, especially as it pertains to the right to life and to the rights of the family.

Third, in the past decade the moral teaching of John Paul II has taken a decisive turn with the publication of two major encyclicals. Veritatis Splendor (1993) provides a detailed overview of Catholic orthodoxy in ethics, especially in the account of the moral act. It also elaborates a critique of certain contemporary tendencies, such as subjectivism and proportionalism, that have distorted moral theology. Evangelium Vitae (1995) offers an extensive defense of the Church's position on human life issues. The encyclical concentrates especially upon the practices of abortion and euthanasia.

These seminal documents became the focus of a renewed Church debate in general and applied ethics. These encyclicals provided the most extensive treatment to date by the pope on the moral questions tormenting the Church. They condemned certain moral theories and practices in the most solemn terms. In fact, the degree of authority of these documents became the object of its own theological dispute.

The encyclicals signaled a maturation in the method of moral analysis used by the pope. Each begins by setting moral questions in the context of biblical narrative: the dialogue between Christ and the rich young man (VS 6-27) and the conflict between Cain and Abel (EV 7-21). Each then proceeds to offer an analysis of the human act strongly influenced by neoscholasticism. Veritatis Splendor insists upon the moral quality of the object of the act, 
rather than motive or circumstance, as the key determinant of an act's moral worth (VS 78). It condemns intrinsically evil acts (VS 79). Evangelium Vitae condemns, as species of intrinsically evil acts, the practice of direct abortion (EV 57) and of active euthanasia (EV 65). Each encyclical elaborates a critique of contemporary society, especially of democratic institutions and mentalities that obscure the moral law. Veritatis Splendor concentrates upon the libertarian (VS 48-53) and utilitarian (VS 71-75) climate of current society, while Evangelium Vitae diagnoses the burgeoning culture of death (EV 68-77).

The encyclicals' synthesis of biblical narrative, act analysis, and social critique provides a distinctive moral rhetoric for the pope. It also presents a model for the renewed moral theology mandated by Vatican Council II (Optatam Totius 16).

The contributors to this volume explore the general orientations and the specific applications of the moral teaching of Pope John Paul II. In the first part of the book, the major papers place the pope's moral theory within a broader theological framework. James Schall, S.J., studies the metaphysical background for this moral theology. Patrick Lynch, S.J., places the pope's ethics within the context of the economy of salvation. John Conley, S.J., limns the concept of conscience in Veritatis Splendor. Ronald Mercier, S.J., studies the Christology behind the pope's ethics. Arthur Madigan, S.J., examines the social and soteriological themes in the morality section of the Catechism of the Catholic Church, the systematic exposition of the Catholic faith promulgated by John Paul II in 1992. These papers and responses attempt to identify the overarching philosophical and theological attitudes that shape the pope's fundamental moral perspective.

In the second part of the work, the major papers study the pope's teaching in the area of applied ethics. Avery Dulles, S.J., examines the pope's conception of culture. John Conley, S.J., analyzes the demographic ethics of John Paul II. John Piderit, S.J., critically evaluates the economic ethics of the pope. Martin Moleski, S.J., considers John Paul II's covenantal theory of marriage. Robert Spitzer, S.J., examines the sexual morality proposed by the pope. Both the major lecturers and the respondents focus upon those areas of applied ethics that have provoked the greatest 
tension between the magisterium and the academy, and between the Church and State in the West.

The volume also includes resumés of the group discussions at the Canisius and Georgetown conferences. These circles focused upon key ethical documents of this pontificate. They permitted Jesuits to discuss the more controverted moral texts of John Paul II and to share their divergent views on the pastoral implications of these teachings.

As a conclusion, the volume presents a homily by Stephen Fields, S.J., originally preached at the 1996 Georgetown conference. The sermon places the ethics of John Paul II within a spiritual framework of repentance and redemption. The pope's moral teaching is not an academic survey of ethical themes. Nor is it a Pelagian call to human self-regeneration. The ultimate truth concerning human conduct and moral judgment emerges only within the proclamation of God's grace.

Rev. John J. Conley, S.J.

Fordham University

New York City

6 August 1998

Transfiguration of the Lord 
